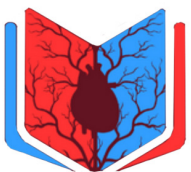

Published By : IVAA the Indonesian Vascular Access Association

\section{Strategy of implementing aerobic exercise as a pleiotropic effect in cancer patients with a history of administration cardiotoxic agents: a systematic review}

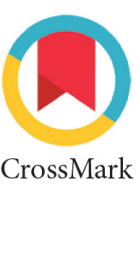

\author{
Putu Yogi Pramana ${ }^{1 *}$, Anak Agung Gede Kesuma Yudha²
}

'Public Health Center Klungkung I, Bali, Indonesia

${ }^{2}$ Faculty of Medicine and Health Science, Universitas Warmadewa, Bali, Indonesia

*Corresponding to:

Putu Yogi Pramana; Public Health Center

Klungkung I, Bali, Indonesia;

yogipramana331@gmail.com
Received:2021-04-26

Accepted: 2021-11-25

Published: 2021-12-28

\section{ABSTRACT}

The development of health science, with the discovery of a type of treatment to reduce mortality due to cancer, namely using chemotherapy agents such as anthracycline and trastuzumab. From the number of studies that have been done, the types of drugs such as anthracycline and trastuzumab have a cardiotoxic effect which is often associated with decreased heart-lung function and the incidence of cardiomyopathy. Exercise is reported to have a pleiotropic effect. Therefore, this study aims to synthesize evidence from the application of pleiotropic exercise in cancer patients undergoing chemotherapy with cardiotoxic agents. The search was performed according to the recommended reporting items for systematic review and meta-analyses (PRISMA). Obtained an accumulation of 2397 articles from PubMed and Google Scholar (2016-2020), which were assisted by the PICO search engine. The article was reviewed by the author within sorting using inclusion and exclusion criteria and obtained 28 articles accordingly. Aerobic exercise has pleiotropic effects by stimulating antioxidants and reducing reactive oxygen species (ROS) levels, reducing pro-apoptosis molecular signaling, stimulating myofilament, facilitating concentric cardia hypertrophy remodeling, and changing cardiac metabolism via adenosine monophosphate (amp) with kinase-mediated. Pretreatment aerobic exercise with minimal supervised 30-min exercise sessions 3 times/week for $\geq 12$ weeks effectively reduce the risk of chemotherapy-induced cardiomyopathy (CRC). Aerobic exercise has a significant pleiotropic effect in patients undergoing chemotherapy with cardiotoxic agents.

Keywords: Cardiomyopathy, Aerobic Exercise, Cardio-protection, Cardiotoxic.

Cite This Article: Pramana, P.Y., Yudha, A.A.G.K. 2021. Strategy of implementing aerobic exercise as a pleiotropic effect in cancer patients with a history of administration cardiotoxic agents: a systematic review. Journal of Indonesia Vascular Access 1(2): 35-40. DOI : 10.51559/jinava.v1i2.12

\section{INTRODUCTION}

According to WHO data in 2018, cancer contributes to 9.6 million deaths worldwide. Cancer is also the second leading cause of death in the world, which is $13 \% .^{1}$ Cancer also affects the psychology and quality of life of patients and their families. Patients with cancer tend to be dependent on others. ${ }^{2}$ The development of health science, with the discovery of a type of treatment to reduce mortality due to cancer, namely using chemotherapy agents such as anthracycline and trastuzumab. ${ }^{2}$

From the number of studies that have been done, the types of drugs such as anthracycline and trastuzumab have a cardiotoxic effect which is often associated with decreased heart-lung function and the incidence of cardiomyopathy. A study by El Vandescruyet et al. in Belgium in 2011 found a $30 \%$ incidence of cardiomyopathy in children with anthracycline-related cancer. ${ }^{3}$ In Indonesia, according to research conducted by Riko in 2014 at RSUP DR M Djamil Padang in 25 adult nasopharyngeal cancer patients, 100\% of patients experienced a decrease in left ventricle ejection fraction (LVEF) after three months of chemotherapy. ${ }^{2}$

The American College of Sports Medicine (ACSM) suggests exercise training has a pleiotropic effect and helps improve quality of life and cancer-related fatigue in cancer survivors. ${ }^{4}$ Prevention of chemotherapy-induced heart failure in high-risk patients is critical for their long-term health. This prevention requires multidisciplinary collaboration between oncologists, cardiologists, and primary care providers. This study aims to analyze evidence from the application of pleiotropic exercise in cancer patients undergoing chemotherapy with cardiotoxic agents.

\section{METHODS}

\section{Searching Literature}

We conducted searches in Google Scholar (from 2016-2020) and PubMed using the PICO engine on the study of chemotherapy-related cardiomyopathy and exercise intervention. Two authors read every title and abstract, obtained full texts of potentially relevant papers, and scrutinized reference lists of included papers. Review inclusion criteria were applied, and uncertainties were discussed with a third author.

\section{Inclusion and Exclusion Criteria}

We included studies if they: (i) were written in English. (ii) were published 
in peer-reviewed journals, (iii) recruited patients at any stage of cancer with a history of administration chemotherapy drug, (iv) patient ages $>18$ years, (v) discuss anthracycline/trastuzumab which induces cardiotoxicity, (vi) relevant aerobic exercise-related cardiotoxic. We excluded case reports, abstracts pediatric studies, dissertations, and articles with less focus on discussing anthracycline-trastuzumab and aerobic exercise also less focus on discussing anthracyclines-trastuzumab in causing cardiotoxic effects.

\section{Data synthesis}

We tabulated results and performed a narrative review of the effect and table based on measuring criteria. We divided the discussion into four categories, based on the assessment indicators namely VO2 max, Left Ventricular Ejection Fraction (LVEF), N-terminal pro-brain natriuretic peptide (NT-proBNP), Framingham score, and LVEF-VO2 max in assessing the effectiveness of exercise training.

\section{LITERATURE REVIEW}

\section{Searching Result}

The electronic search identified 2390 citations, and 33 full texts were retrieved for detailed evaluation (Figure 1) five studies were excluded. The main reason for exclusion was that the studies are less focused on discussing the combination of anthracycline-trastuzumab and aerobic exercise. Ten studies (total number 515 patients, range 18-55 years old) fulfilled our inclusion criteria. Three of these studies examined the impact of exercise training on the observed cardiotoxic effects of VO2 max. One of them used NT Pro BNP as a reference, Three other studies used Left Ventricle Ejection Fraction (LVEF) as a reference. One study explained Framingham's risk score as an indicator to assess the exercise effect. and eighteen studies presented data as a reference in discussing exercise training related to cardiotoxicity effect from the use of chemotherapy drugs.

\section{Cancer-Related Cardiomyopathy (CRC)}

CRC is a heart disorder related to the use of drugs, especially chemotherapy drugs, with various causes of pathomechanism.
Furthermore, CRC classified into two types, type 1 is associated with permanent or irreversible effects while type 2 is reversible while influenced by dose, administration, age, sex, and the presence of comorbidities. ${ }^{5}$

\section{Anthracycline Mechanism Exerts Car- diotoxic Effects}

The effectiveness of anthracycline (ACs) in chemotherapy treatment makes it the mainstay of therapy used. The use of ACs cause Left Ventricle (LV) dysfunction and heart failure in a dose-dependent manner. However, there is no threshold dose below which cardiotoxicity does not occur. Although the mechanism of ACs causing cardiotoxic effects has not been clearly defined, there are several hypotheses to explain this situation. ${ }^{7}$

The first hypothesis related to ROS suggests that increased concentration

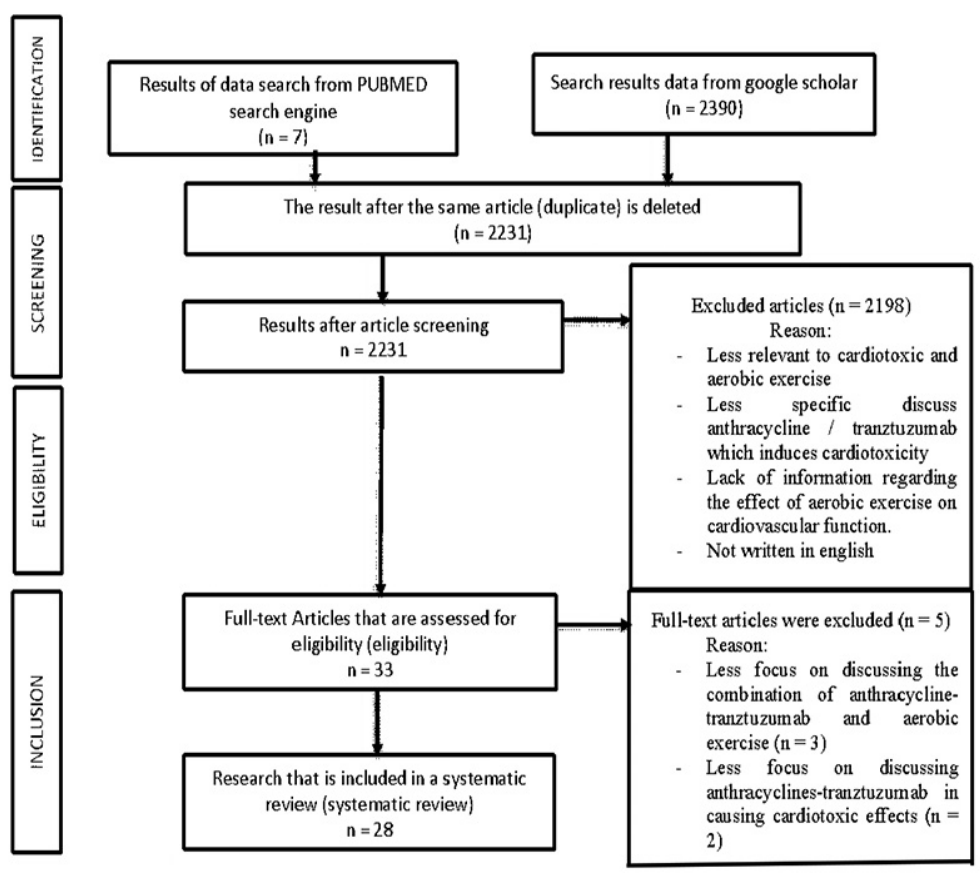

Figure 1. Flow diagram of included and excluded studies.

Table 1. Type 1 and 2 Cancer-Related Cardiomyopathy (CRC). ${ }^{6}$

\begin{tabular}{lll}
\multicolumn{1}{c}{ Differences } & \multicolumn{1}{c}{ Type 1 } & \multicolumn{1}{c}{ Type 2 } \\
\hline $\begin{array}{l}\text { Types of } \\
\text { Chemotherapy }\end{array}$ & $\begin{array}{l}\text { Doxorubicin, mitoxantone dan } \\
\text { siklofospamid }\end{array}$ & Trastuzumab, imatinib, sunitinib \\
$\begin{array}{l}\text { Clinical } \\
\text { manifestations }\end{array}$ & $\begin{array}{l}\text { Clinically stable but permanent } \\
\text { and irreversible damage to heart } \\
\text { tissue }\end{array}$ & $\begin{array}{l}\text { Can return to the original heart } \\
\text { condition (reversible) in 2-4 months }\end{array}$ \\
The dose effect & $\begin{array}{l}\text { Cumulative, depending on the } \\
\text { dose }\end{array}$ & Dose Independent \\
Mechanism & $\begin{array}{l}\text { The formation of free radicals or } \\
\text { oxidative stress }\end{array}$ & $\begin{array}{l}\text { Blocks the EerbB2 signal } \\
\text { Pathological } \\
\text { findings }\end{array}$ \\
$\begin{array}{l}\text { The vacuole, myocyte tissue } \\
\text { damage }\end{array}$ & $\begin{array}{l}\text { There were no abnormalities in the } \\
\text { large structures }\end{array}$ \\
back & $\begin{array}{l}\text { There is a high chance of relapse } \\
\text { and progressive heart dysfunction } \\
\text { which can lead to heart failure and } \\
\text { cardiomyopathy }\end{array}$ & $\begin{array}{l}\text { Most of the literature says it is } \\
\text { safe to be given a second time, but } \\
\text { further research is still needed }\end{array}$ \\
\hline
\end{tabular}


of ROS leads to increased expression of proteins that are involved in cardiac autophagy, pathological myocardial hypertrophy via calcium overload, and inhibition of myoprotein synthesis. ${ }^{8,9}$ The topoisomerase (Top) 2B hypothesis suggests that $\mathrm{ACs}$ bind to Top $2 \mathrm{~B}$, distorting its structure and preventing Top 2B from unwinding DNA. ${ }^{7}$ This action causes double-stranded DNA breaks, activates apoptotic pathways, and causes cardiomyocyte death. The Top 2B hypothesis could potentially initiate the pathway of the ROS hypothesis where inactivated Top $2 \mathrm{~B}$ reduces antioxidant gene transcription and leads to increased ROS production. ${ }^{7}$

\section{The Trastuzumab Mechanism Exerts Cardiotoxic Effects}

Trastuzumab disrupts (Human epidermal growth factor receptor) HER signaling by inducing phosphorylation of HER1 and HER2 at 845 and 1248 sites, respectively, and activates autophagy-inhibitory Erk/mTOR/Ulk 1 signaling cascade, thereby compromising cardiomyocyte's ability to recycle toxic cellular and increase reactive oxygen species (ROS) accumulate substrates causing cardiotoxicity. Trastuzumab-induced cardiac dysfunctions were regarded as less severe and largely reversible because primary cardiomyocyte did not show ultrastructure changes that were associated with anthracycline-induced cardiotoxicity, and primary myocyte injury did not occur in patients that were treated with trastuzumab. ${ }^{10}$

\section{VO2 max}

Physical fitness determines a person's capacity to carry out an activity and affects health. $\mathrm{VO} 2$ max is a measurement for the amount of oxygen distributed to all muscles which is the result of the maximum cardiac output and maximal O2 extraction from the tissue during exercise which is used for the purposes of cell metabolism and energy production for the body. VO2 max is often used as a reflection of cardiorespiratory function. ${ }^{11}$

Exercise is scientifically proven to increase VO2 max capacity as shown in a

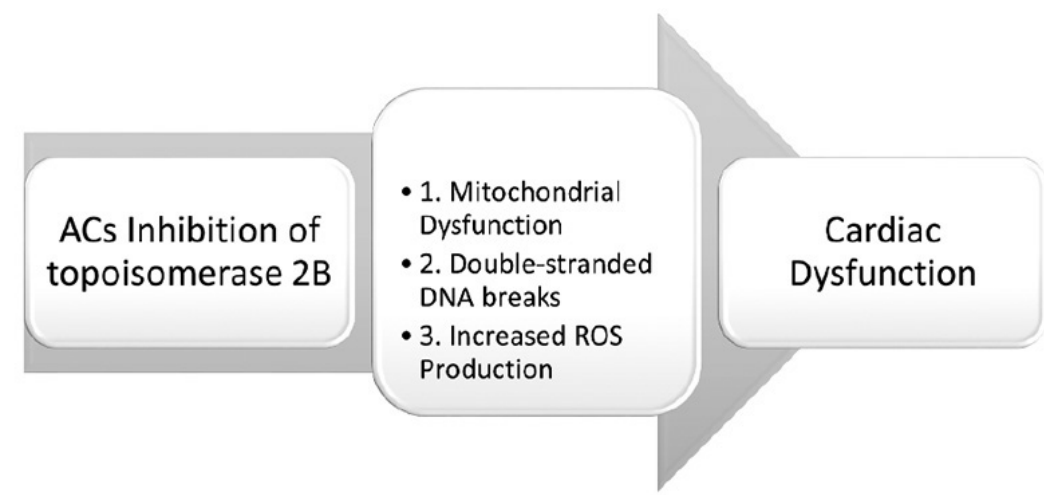

Figure 2. Potential mechanisms of anthracycline (ACs)-induced cardiotoxicity (1-3) cause cardiac dysfunction. ${ }^{7}$

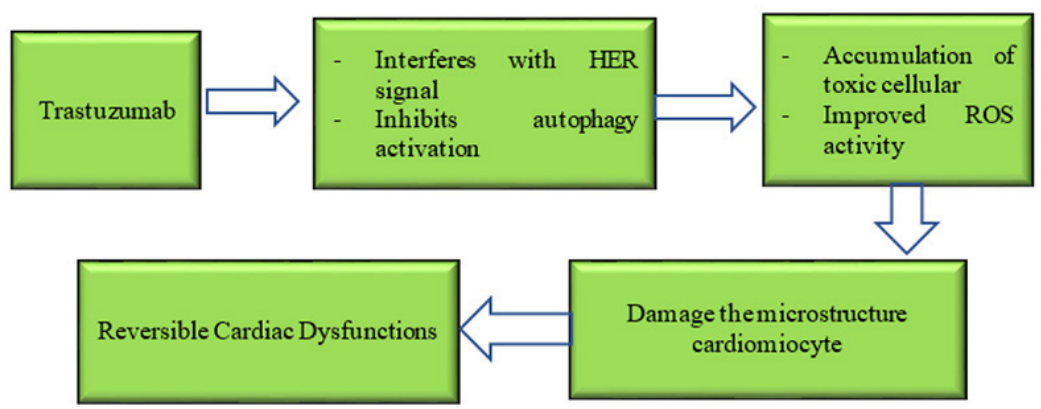

Figure 3. Potential mechanisms of Trastuzumab-induced cardiotoxicity. ${ }^{10}$ randomized control trial (RCT) conducted by Kyuwan Lee et al. in 2019, 30 patients with stage 1 and 2 breast cancer who had the habit of sitting and were receiving anthracycline chemotherapy with doxorubicin every 2 weeks 4 cycles showed that high-intensity exercise 3 times a week for 30 minutes in 8 weeks could increase VO2 max capacity. ${ }^{12}$ Similar results were also obtained by the RCT study Zakaria Mowafy et al. in 2016, 40 breast cancer patients aged 35-55 years who were receiving anthracycline chemotherapy were divided into two groups, namely group a (recipients of aerobic-cycling for 25 minutes per day for 4 months and anthracycline intervention) and group b (anthracycline only) and it turned out that group A gave a significant increase in $\mathrm{VO} 2$ max. ${ }^{13}$ Similar to the research of Zakaria Mowafy et al, Scott C. Adams et al. in his 2017 RCT study conducted on 63 stages 1-3 testicular cancer patients receiving anthracycline chemotherapy who were given intervention in the form of thriceweekly supervised exercise sessions total of 35 minutes in one session during 6 weeks program showed a significant increase in the patient's VO2 max. ${ }^{14}$

Based on the results of these studies, aerobic exercise which is done 3 times a week with a duration of 25-35 minutes per day for 6-16 weeks has been shown to increase VO2 max capacity so that it can prevent cardiotoxic effects on cancer patients who received chemotherapy agents.

\section{LVEF}

Left Ventricle Ejection Fraction (LVEF) is an indicator used to assess heart function, especially the left ventricle. LVEF is a measurement of the volume of blood pumped out of the left ventricle. According to the Indonesian cardiologist association, LVEF has a normal range value of $>45 \%{ }^{15}$ A decrease in the value of the LVEF represents a decrease in cardiovascular function. Exercise will increase cardiac output. Increased cardiac output will increase LVEF. Increased cardiac output can be achieved by doing exercise. ${ }^{16}$

RCT study of Quentin Jacquinot et al. in 2017, 112 breast cancer patients with stage 1-3 who received trastuzumab therapy with HER 2 were positive, after 
being given an intervention supervised exercise program (intermittent exercise, combining moderate and high intensities; 55 minutes duration, 3 times per week) in 3 months. Result obtained an increase in LVEF by $50 \%$ from the previous LVEF value of $35 \% .{ }^{17}$

Similar results were obtained in the RCT study conducted by Costello Benedict T. et al. in 2019, 27 breast cancer patients with stage 1-2 receiving anthracycline chemotherapy were treated in the form of a moderate- to vigorous-intensity aerobic and resistance training regimen $(3 \mathrm{x} /$ week,
$60 \mathrm{~min} / \mathrm{session}$ 2supervised, 1homebased) for 6 weeks significantly increased the left ventricular ejection fraction. ${ }^{18}$ Inversely to the RCT study conducted by Amy A. Kirkham et al. in 2020, 26 breast cancer patients receiving anthracycline chemotherapy (doxorubicin) were given treatment in the form of treadmill exercise with a duration of 20 to 30 minutes 2 times per week for 2 weeks of giving doxorubicin was proven not to significantly improve LVEF function. ${ }^{19}$

Based on the results of this study, it can be concluded that the exercise that is carried out within 2 weeks has not had an impact, while 3 times a week of exercise training with a duration of 55-60 minutes for 6-12 weeks has been shown to increase and improve LVEF function so that it can prevent cardiotoxic effects from Chemotherapy.

\section{NT Pro BNP}

N-Terminal Pro Brain Natriuretic Peptide (NT Pro BNP) is a type of hormone produced by ventricular myocyte cells in response to increased pressure on the ventricular wall. Increased pressure

Table 2. Research summary of the application of exercise training

\begin{tabular}{|c|c|c|c|c|c|}
\hline $\begin{array}{l}\text { Author } \\
\text { (year) }\end{array}$ & Malignancy & $\begin{array}{l}\text { Number of } \\
\text { samples }\end{array}$ & Indicator & Intervention & Outcome \\
\hline $\begin{array}{l}\text { Kyuwan lee et } \\
\text { al. (2019) }\end{array}$ & $\begin{array}{l}\text { Breast cancer } \\
\text { stages } 1 \text { and } 2\end{array}$ & 30 & $\begin{array}{l}\text { VO2 max } \\
\text { capacity }\end{array}$ & $\begin{array}{l}\text { High-intensity exercise training that is done } 3 \\
\text { times a week for } 30 \text { minutes for } 8 \text { weeks }\end{array}$ & $\begin{array}{l}\text { Increase } \mathrm{VO} 2 \text { max } \\
\text { capacity }\end{array}$ \\
\hline $\begin{array}{l}\text { Zakaria } \\
\text { Mowafy et al. } \\
(2016)\end{array}$ & $\begin{array}{l}\text { Breast cancer } \\
\text { patients aged } \\
35-55 \text { years }\end{array}$ & 40 & $\begin{array}{l}\mathrm{VO} 2 \max \\
\text { capacity }\end{array}$ & $\begin{array}{l}\text { Aerobic cycling for } 25 \text { minutes per day for } 4 \\
\text { months }\end{array}$ & $\begin{array}{l}\text { Increase } \mathrm{VO} 2 \text { max } \\
\text { capacity }\end{array}$ \\
\hline $\begin{array}{l}\text { Scott C. } \\
\text { Adams et al. } \\
(2017)\end{array}$ & $\begin{array}{l}\text { Testicular cancer } \\
\text { patients stage } \\
1-3\end{array}$ & 63 & $\begin{array}{l}\text { VO2 max } \\
\text { capacity }\end{array}$ & $\begin{array}{l}\text { Thrice-weekly supervised exercise sessions total } \\
\text { of } 35 \text { minutes in one session during } 6 \text { weeks }\end{array}$ & $\begin{array}{l}\text { Increase } \mathrm{VO} 2 \text { max } \\
\text { capacity }\end{array}$ \\
\hline $\begin{array}{l}\text { Quentin } \\
\text { Jacquinot et } \\
\text { al.(2017) }\end{array}$ & $\begin{array}{l}\text { Breast cancer } \\
\text { stage } 1-3\end{array}$ & 112 & LVEF & $\begin{array}{l}3 \text { months supervised exercise program } \\
\text { (intermittent exercise, combining moderate and } \\
\text { high intensities; } 55 \text { minutes duration, } 3 \text { times per } \\
\text { week) }\end{array}$ & Increase in LVEF \\
\hline $\begin{array}{l}\text { Costello } \\
\text { Benedict T. et } \\
\text { al. (2019) }\end{array}$ & $\begin{array}{l}\text { Breast cancer } \\
\text { stage } 1-2\end{array}$ & 27 & LVEF & $\begin{array}{l}\text { Moderate- to vigorous-intensity aerobic and } \\
\text { resistance training regimen ( } 3 \mathrm{x} / \text { week, } 60 \mathrm{~min} / \\
\text { session, } 2 \text { supervised, } 1 \text { home-based) for } 6 \text { weeks }\end{array}$ & Increase in LVEF \\
\hline $\begin{array}{l}\text { Amy A. } \\
\text { Kirkham et } \\
\text { al.(2020) }\end{array}$ & Breast cancer & 26 & LVEF & $\begin{array}{l}\text { Treadmill exercise with a duration of } 20 \text { to } 30 \\
\text { minutes } 2 \text { times per week for } 2 \text { weeks of giving } \\
\text { doxorubicin }\end{array}$ & $\begin{array}{l}\text { Did not significantly } \\
\text { improve the LVEF } \\
\text { function }\end{array}$ \\
\hline $\begin{array}{l}\text { Kirkham, A et } \\
\text { al.(2020) }\end{array}$ & $\begin{array}{l}\text { Breast cancer } \\
\text { stage } 1-3\end{array}$ & 27 & NT-Pro BNP & $\begin{array}{l}\text { Treadmill exercise for } 24 \text { hours before starting } \\
\text { doxorubicin therapy for } 45 \text { minutes }\end{array}$ & $\begin{array}{l}\text { Significantly } \\
\text { inhibits NT-Pro } \\
\text { BNP secretion and } \\
\text { improves cardiac } \\
\text { systolic function }\end{array}$ \\
\hline $\begin{array}{l}\text { Kyuwan Lee } \\
\text { et al.(2019) }\end{array}$ & $\begin{array}{l}\text { Breast cancer } \\
\text { stage } 1-3\end{array}$ & 100 & $\begin{array}{l}\text { Framingham } \\
\text { risk score }\end{array}$ & $\begin{array}{l}\text { Aerobic and resistance exercise } 3 \text { times a week } \\
\text { for } 150 \text { minutes for } 16 \text { weeks }\end{array}$ & $\begin{array}{l}\text { Significantly lowered } \\
\text { the Framingham risk } \\
\text { score }\end{array}$ \\
\hline $\begin{array}{l}\text { Edward Tsai } \\
\text { et al.(2019) }\end{array}$ & $\begin{array}{l}\text { Patient with HF } \\
\text { NYHA class } \\
\text { I, II and III } \\
\text { with history of } \\
\text { anthracyclyne } \\
\text { chemotherapy }\end{array}$ & 20 & $\begin{array}{l}\text { VO2 max and } \\
\text { LVEF }\end{array}$ & $\begin{array}{l}\text { The exercise program was based on HF-ACTION } \\
\text { and consisted of supervised } 30 \text { minutes exercise } \\
\text { sessions } 3 \text { times/week for } 16 \text { week " } 6-20 \text { " rating } \\
\text { of perceived exertion (RPE) }\end{array}$ & $\begin{array}{c}\text { Significant } \\
\text { improvements in } \\
\text { VO2 max and LVEF }\end{array}$ \\
\hline $\begin{array}{l}\text { Zhijun Ma } \\
(2018)\end{array}$ & $\begin{array}{l}\text { Women with } \\
\text { breast cancer } \\
\text { after Operation } \\
\text { with history of } \\
\text { administration } \\
\text { chemotherapy }\end{array}$ & 70 & $\begin{array}{l}\text { VO2 max and } \\
\text { LVEF }\end{array}$ & Aerobic exercise during 50 minutes in 16 weeks & $\begin{array}{c}\text { significant } \\
\text { improvements in } \\
\text { VO2 max and LVEF }\end{array}$ \\
\hline
\end{tabular}


(stress) on the ventricular walls is often associated with myocardial damage that can be caused by chemotherapy. Exercise can prevent the formation of ROS which has inflammatory effect so as to prevent the increase in NT Pro BNP. ${ }^{20}$

This statement is evidenced by the RCT study conducted by Kirkham, A et al. in 2020, 27 patients with stage 1-3 breast cancer received anthracycline chemotherapy who were given intervention treadmill exercise for 24 hours before starting doxorubicin therapy for 45 minutes significantly inhibits NTPro BNP secretion and improves cardiac systolic function. ${ }^{21}$ Based on the results of this study, it can be concluded that the exercise carried out 24 hours before chemotherapy for 45 minutes was proven to inhibit the formation of NT-Pro BNP, thereby preventing the occurrence of cardiotoxic effects due to chemotherapy use.

\section{Framingham Risk Score}

The Framingham risk score is a scoring system developed by the Canadian Cardiovascular Society which is used to predict the incidence of cardiovascular disease for the next 10 years. ${ }^{22,23}$ One way to reduce the risk of cardiovascular disease is exercise. This can be proven from the RCT study conducted by Kyuwan Lee et al. in 2019, 100 stage 1-3 breast cancer patients receiving anthracycline chemotherapy who were given treatment in the form of aerobic and resistance exercise 3 times a week for 150 minutes for 16 weeks significantly reduced the Framingham risk score. $^{24}$

\section{LVEF dan VO2 Max}

Increased LVEF and VO2 max represent a good cardiovascular function. Increased LVEF and VO2 max can occur due to increased cardiac output caused by exercise. This is consistent with the RCT study conducted by Edward Tsai et al. in 2019, 20 HF NYHA class I, II, and III patients with a history of anthracycline chemotherapy were given an intervention HF-ACTION-based exercise program and consisted of a 30-minute guided exercise session 3 times/week for 16 weeks. The "6-20" rating of perceived exertion (RPE) significant improvement in VO2max and
LVEF was observed in the intervention group. ${ }^{25}$

Similar results were also obtained from RCT research conducted by Zhijun $\mathrm{Ma}$ in 2018 on 70 women with breast cancer after surgery for anthracycline chemotherapy recipients who were given the intervention of aerobic exercise for 50 minutes within 16 weeks to increase VO2 max and LVEF and to some extent, it could reverse the damage of chemotherapy drugs to the heart. ${ }^{26}$ Based on the results of these studies, exercise was carried out 3 times per week for 30-50 minutes in 16 weeks has been shown to increase $\mathrm{VO} 2$ max and LVEF, so that it can maintain cardiovascular function and prevent cardiotoxic effects from Chemotherapy.

\section{CONCLUSION}

Based on the results of a systematic review, it was found that aerobic exercise has a significant pleiotropic effect in patients undergoing chemotherapy with cardiotoxic agents by stimulating antioxidants and reducing elevated ROS levels, reducing proapoptotic molecular species and signaling, stimulation of myofilament synthesis, facilitating physiological concentric hypertrophy in myocardial remodeling and altering cardiac metabolism through AMPmediated kinases. Pretreatment aerobic exercise 24 hours before chemotherapy anthracycline-trastuzumab with minimal supervised 30-min exercise sessions 3 times/week for $\geq 12$ weeks effective reduce risk of CRC. Hopefully, these findings can be useful for health workers as a strategy to prevent and reduce comorbidity due to the use of chemotherapy drugs.

\section{ACKNOWLEDGMENT}

The author would like to thank Ni Putu Nita Cahyawati for their help designing search strategies. This work was supported by the Faculty of Medicine and Health Science, Warmadewa University, Bali, Indonesia.

\section{FUNDING}

This article did not use sponsorship funds and purely use author funds

\section{CONFLICT OF INTEREST}

There is no conflict of interest in this article and all funding does not involve a specific sponsor or brand

\section{AUTHOR CONTRIBUTION}

In this article, all authors are involved and take part in making the article. the first author contributed to drafting and designing this manuscript. the second author provides concepting, designing, and supervising the manuscript.

\section{ETHICAL STATEMENT}

Not applicable

\section{REFERENCES}

1. Organization WH. WHO report on cancer: setting priorities, investing wisely and providing care for all [Internet]. Geneva PP - Geneva: World Health Organization; Available from: https://apps.who.int/iris/handle/10665/330745

2. Faiza S, Rahman S, Asri A. Karakteristik Klinis dan Patologis Karsinoma Nasofaring di Bagian THT-KL RSUP Dr.M.Djamil Padang. J Kesehat Andalas. 2016;5(1):90-6.

3. Friedel M, Brichard B, Fonteyne C, Renard M, Misson J-P, Vandecruys E, et al. Building Bridges, Paediatric Palliative Care in Belgium: A secondary data analysis of annual paediatric liaison team reports from 2010 to 2014. BMC Palliat Care. 2018;17(1):77. Available from: https://pubmed.ncbi.nlm.nih.gov/29788956

4. Schmitz KH, Courneya KS, Matthews C, Demark-Wahnefried W, GALVÃO DA, Pinto BM, et al. American College of Sports Medicine Roundtable on Exercise Guidelines for Cancer Survivors. Med Sci Sport Exerc. 2010;42(7):1409-26. Available from: http:// dx.doi.org/10.1249/mss.0b013e3181e0c112

5. Westphal JG, Schulze PC. Exercise training in cancer related cardiomyopathy. J Thorac Dis. 2018;10(Suppl 35):S4391-9. Available from: https://pubmed.ncbi.nlm.nih.gov/30701106

6. Chen JJ, Wu P-T, Middlekauff HR, Nguyen K-L. Aerobic exercise in anthracyclineinduced cardiotoxicity: a systematic review of current evidence and future directions. Am J Physiol Heart Circ Physiol. 2016/12/06. 2017;312(2):H213-22. Available from: https:// pubmed.ncbi.nlm.nih.gov/27923793

7. Vejpongsa P, Yeh ETH. Prevention of Anthracycline-Induced Cardiotoxicity. J Am Coll Cardiol. 2014;64(9):938-45. Available from: http://dx.doi.org/10.1016/j.jacc.2014.06.1167

8. Scott JM, Khakoo A, Mackey JR, Haykowsky MJ, Douglas PS, Jones LW. Modulation of anthracycline-induced cardiotoxicity by aerobic exercise in breast cancer: current evidence and underlying mechanisms. Circulation. 2011;124(5):642-50. Available from: https:// pubmed.ncbi.nlm.nih.gov/21810673 
9. Smuder AJ, Kavazis AN, Min K, Powers SK. Doxorubicin-induced markers of myocardial autophagic signaling in sedentary and exercise trained animals. I Appl Physiol. 2013;115(2):176-85. Available from: http:// dx.doi.org/10.1152/japplphysiol.00924.2012

10. Onitilo AA, Engel JM, Stankowski R V. Cardiovascular toxicity associated with adjuvant trastuzumab therapy: prevalence, patient characteristics, and risk factors. Ther Adv drug Saf. 2014;5(4):154-66. Available from: https://pubmed.ncbi.nlm.nih.gov/25083270

11. de Carvalho Souza Vieira M, Boing L, Leitão AE, Vieira G, Coutinho de Azevedo Guimarães A. Effect of physical exercise on the cardiorespiratory fitness of men-A systematic review and meta-analysis. Maturitas. 2018;115:23-30. Available from: http://dx.doi. org/10.1016/j.maturitas.2018.06.006

12. Lee K, Kang I, Mack WJ, Mortimer J, Sattler F, Salem G, et al. Feasibility of high intensity interval training in patients with breast Cancer undergoing anthracycline chemotherapy: a randomized pilot trial. BMC Cancer. 2019;19(1):653. Available from: https:// pubmed.ncbi.nlm.nih.gov/31269914

13. Mowafy ZME, Zoheiry IMI, Elmonem MGA, Katter D. Efficacy of aerobic training on maximal oxygen consumption and total leukocytes count after chemotherapy in breast cancer patients. Int J PharmTech Res. 2016;9(4):34-40.

14. Adams SC, DeLorey DS, Davenport MH, Stickland MK, Fairey AS, North S, et al. Effects of high-intensity aerobic interval training on cardiovascular disease risk in testicular cancer survivors: A phase 2 randomized controlled trial. Cancer. 2017;123(20):4057-65. Available from: http://dx.doi.org/10.1002/cncr.30859

15. PP PERKI. Pedoman Tatalaksana Gagal Jantung 2020. 2nd ed. Perhimpun Dr Spes Kardiovask Indones 2020. 2020;6(11):951-2.
16. Rocha BML, Lopes Da Cunha GJ, Lopes PMD, Freitas PN, Gama F, Brizido C, et al. Risk stratification in $\mathrm{hf}$ with mid-range LVEF: the role of cardiopulmonary exercise testing. Eur Heart J. 2020;41(Supplement_2). Available from: http://dx.doi.org/10.1093/ehici/ ehaa946.0940

17. Jacquinot $\mathrm{Q}$, Meneveau $\mathrm{N}$, Chatot $\mathrm{M}$, Bonnetain F, Degano B, Bouhaddi M, et al. A phase 2 randomized trial to evaluate the impact of a supervised exercise program on cardiotoxicity at 3 months in patients with HER2 overexpressing breast cancer undergoing adjuvant treatment by trastuzumab: design of the CARDAPAC study. BMC Cancer. 2017;17(1):425. Available from: https://pubmed.ncbi.nlm.nih.gov/28629338

18. Costello BT, Roberts TJ, Howden EJ, Bigaran A, Foulkes SJ, Beaudry RI, et al. Exercise Attenuates Cardiotoxicity of Anthracycline Chemotherapy Measured by Global Longitudinal Strain. JACC CardioOncology. 2019;1(2):298-301. Available from: https://pubmed.ncbi.nlm.nih. gov/34396194

19. Kirkham AA, Virani SA, Bland KA, McKenzie DC, Gelmon KA, Warburton DER, et al. Exercise training affects hemodynamics not cardiac function during anthracyclinebased chemotherapy. Breast Cancer Res Treat. 2020;184(1):75-85. Available from: http:// dx.doi.org/10.1007/s10549-020-05824-x

20. Kamelia T, Waspadji S, Makmun LH, Effendi S, Ramli M, Timan IS. Perubahan Konsentrasi Amino Terminal Pro B-Type Natriuretic Peptide (NT-proBNP) dan Fraksi Ejeksi Ventrikel Kiri pada Pasien Kemoterapi Doksorubisin. J Penyakit Dalam Indones. 2017;4(2):78. Available from: http://dx.doi.org/10.7454/jpdi.v4i2.127

21. Kirkham AA, Eves ND, Shave RE, Bland KA, Bovard J, Gelmon KA, et al. The effect of an aerobic exercise bout $24 \mathrm{~h}$ prior to each doxorubicin treatment for breast cancer on markers of cardiotoxicity and treatment symptoms: a RCT. Breast Cancer Res Treat. 2017;167(3):719-29. Available from: http:// dx.doi.org/10.1007/s10549-017-4554-4

22. Law W, Johnson C, Rushton M, Dent S. The Framingham risk score underestimates the risk of cardiovascular events in the HER2positive breast cancer population. Curr Oncol. 2017/10/25. 2017;24(5):e348-53. Available from: https://pubmed.ncbi.nlm.nih. gov/29089804

23. Kusnandang A. Framingham Score dan Jakarta Cardivascular Score untuk Menentukan Kejadian Cardiovaskuler Event Pekerja Rumah Sakit Pertamina Cirebon. J Kedokt dan Kesehat. 2018;1-5.

24. Lee K, Tripathy D, Demark-Wahnefried W, Courneya KS, Sami N, Bernstein L, et al. Effect of Aerobic and Resistance Exercise Intervention on Cardiovascular Disease Risk in Women With Early-Stage Breast Cancer: A Randomized Clinical Trial. JAMA Oncol. 2019;5(5):710-4. Available from: https://pubmed.ncbi.nlm.nih. gov/30920602

25. Tsai E, Mouhayar E, Lenihan D, Song J, Durand J-B, Fadol A, et al. Feasibility and Outcomes of an Exercise Intervention for ChemotherapyInduced Heart Failure. J Cardiopulm Rehabil Prev. 2019;39(3):199-203. Available from: https://pubmed.ncbi.nlm.nih.gov/31022003

26. Ma Z. Effect of anthracycline combined with aerobic exercise on the treatment of breast cancer. Pak J Pharm Sci. 2018;31(3(Special)):1125-9. 